\title{
Spatial Integration of Selected Potato Markets in Assam
}

\author{
A. Tovinoli Shohe* and C. Hazarika
}

Department of Agricultural Economics \& Farm Management, Assam Agricultural University, Jorhat-785013, India

*Corresponding author: soetovi@gmail.com (ORCID ID: 0000-0002-5681-966X)

Received: $19-04-2019$

Revised: $15-07-2019$

Accepted: 26-08-2019

\begin{abstract}
The present study analyzes the spatial integration through cointegration analysis on the wholesale monthly prices of potato in five selected markets of Assam for the period January 2013 to December 2018. The results of the analysis revealed that markets under study are integrated. The Granger Causality Test reveals 1 bi-directional and 8 uni-directional causations under different market situations. However, the study finds no cointegration between Sonitpur (Dhekiajuli) and Nagaon (Dhing) market. Kamrup Rural (Upharhali) market was identified as the leader market. The study suggests the need to focus on building an improved market information system, one that is able to disseminate timely market information about price, demand and supply of products as well as strengthen market infrastructure facilities inorder to increase the efficiency of potato markets in Assam.

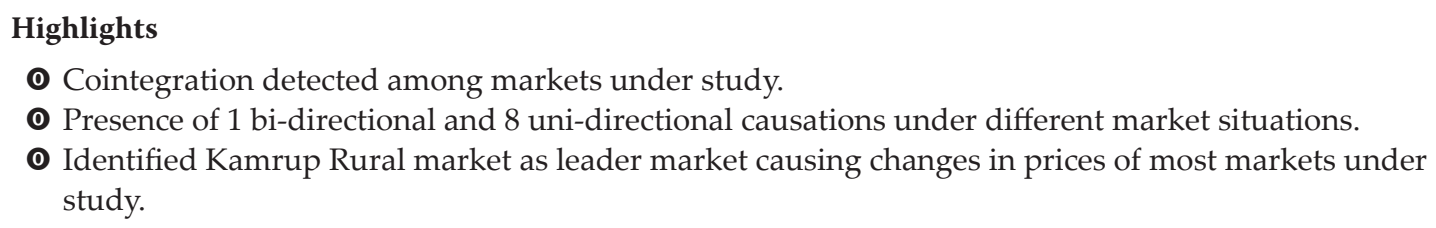

Keywords: Assam, potato, cointegration, markets

The spread of price information is an important factor that affects market. It is believed that prices quoted are a reflection of the conditions prevalent in the markets (Anwal et al. 2007). Market cointegration has positive relationship with market efficiency and market competitiveness. According to Ahmed and Singla, (2017) the high degree of market integration indicates the competitiveness of the markets and the well-integrated market provides the ways for the farmers to specialize according to comparative advantage. Also, an efficient functioning of markets is an essential prerequisite of a sound marketing system to provides remunerative prices for the produce of the farmer as well as provide goods at reasonable prices to the consumers. If the markets are integrated then the resources are allocated effectively, whereas poor integration leads to misallocation of resources which in-turn causes price fluctuations pronounced more particularly in one market or the other (Venujayakanth et al. 2017). One of the common indicators of an efficient functioning of the markets is the existence of high degree of integration among them. Integrated markets have limited price differences in time, form, and space when it comes to marketing costs (Kumar and Mishra, 2016). Typically, agricultural products are bulky and perishable in nature resulting in high unit cost of transportation and storage. In a competitive market where there exists free flow of information, the price difference between any two markets should be equal to or less than transport costs between the two markets. According to Sanogo and Maliki (2010), price changes in one market will be transmitted on a "one-to-one" basis to the other market either instantaneously or over a number of lags. The inter-regional markets located at distant places from the place of production and the resultant price differences provide an important feedback on 
understanding the market (Wani et al. 2015). Further, the various costs involved in transporting the produce especially the perishables from the point of production to market yard is of grave concern for the producer. Thus, the analysis of price movements for the commodity in the corresponding and linked markets helps in judging the extent of efficiency of the marketing system in the region for the selected crops (Singh, 2014).

Potato is one of the most important and widely cultivated vegetable crops in Assam and ranks fourth in terms of acreage under individual crop in the state (Borah et al. 2016). The state also occupies $6^{\text {th }}$ position in area and $7^{\text {th }}$ position in production among the major growing states in the country and has a share of about 2.27 per cent to total country's potato production (NHB, 2017). In Assam, during 2016-17, total production of potato was 777.83 thousand tonnes and area under it was 106.44 thousand hectares with a yield of $7308 \mathrm{~kg} /$ ha (GoA, 2017). The crop is grown in all districts of the state, however, major producing districts are Barpeta, Lakhimpur, Darrang, Sonitpur, Nagaon and Kamrup and Kokrajhar. Although many studies on marketing of potato has been conducted, yet, studies in relation to spatial integration is lacking. In this backdrop, the present study was carried out to examine the spatial price relationship of potato in selected markets of Assam.

\section{MATERIALS AND METHODS}

\section{Data base}

The data on wholesale prices of potato for the period January 2013 to December 2018 was collected from AGMARKNET website. Five districts were selected based on major production areas and from each district, one market was selected, viz, Howly (Barpeta), Dhekiajuli (Sonitpur), Darrang (Darrang), Dhing (Nagaon) and Uparhali (Kamrup Rural) based on availability of consistent data for the period under consideration.

\section{Test for unit roots}

Before proceeding to test the co integration, it is necessary to examine the univariate time series properties of the data and confirm that all the price series are nonstationary and integrated of same order. To test the null hypothesis of non-stationary against an alternative of stationary, Augmented Dickey-Fuller (ADF) test was applied. The ADF test is a parametric test (pre-determined parameters), and estimates the regression equations; under the null hypotheses $\mathrm{H}_{0}: \delta=0$ (existence of unit root or non-stationary time series) against the $H_{1}: \delta<0$.

\section{Johansen co integration Test}

Following Johansen and Juselius (1990), the ML method of co integration may be briefly outlined here. If $P_{t}$ denotes an $(n \times 1)$ vector of $I(1)$ prices, then the $k$-th order VAR representation of $P_{t}$ may be written as:

$$
P_{t}=\sum_{i=1}^{k} \Pi_{i} P_{t-1}+\varepsilon_{t}(t=1,2 \ldots T)
$$

The procedure for testing co-integration is based on the error correction representation of $P_{i}$ given by:

$$
\Delta P_{t}=\sum_{i=1}^{k-1} \Gamma \Delta P_{t-1}+\Pi P_{t-k}+\varepsilon_{t}
$$

Where, $\Gamma_{i}=-\left(I-\Pi_{1}-\ldots \ldots-\Pi_{t}\right) ; i=1,2, \ldots \ldots k-1$

and $\Pi=-\left(I-\Pi_{1}-\ldots \ldots,-\Pi_{k}\right)$

Each of $\Pi_{1}$ is $n \times n$ matrix of parameters; $\varepsilon_{t}$ is an independently distributed $n$-dimensional vector of residuals with zero mean and variance matrix. Since $P_{t-k}$ is $I(1)$, but $\Delta P_{t}$ and $\Delta P_{t-i}$ variables are $I(0)$, equation (1) will be balanced if is $I(0)$. So, it is the matrix that conveys information about long-run relationship among the variables in $P_{t}$. The rank of $\Pi$, $r$, determines the number of cointegrating vectors, as it determines how many linear combinations of $P_{t}$ is stationary. If $r=n$, the prices are stationary in levels. If $r=0$, no linear combination of $P_{t}$ is stationary. If $0<\operatorname{rank}(\Pi)=r<n$ (Enders 1995), and there are $n \times$ $r$ matrices $\alpha$ and $\beta$ such that $\Pi=\alpha \beta^{\prime}$, then it can be said that there are $r$ cointegrating relations among the elements of $P_{t}$. The cointegrating vector $\beta$ has the property that $\beta^{\prime} P_{t}$ is stationary even though $P_{t}$ itself is non-stationary. The matrix $\alpha$ measures the strength of the cointegrating vectors in the ECM, as it represents the speed of adjustment parameters.

Johansen proposes two different likelihood ratio tests of significance of these canonical correlations and thereby the reduced rank of the matrix: the trace test and maximum eigenvalue test as shown in equations below, 


$$
\begin{aligned}
& J_{\text {trace }}=-T \sum_{i=r+1}^{n} \ln \left(1-\lambda_{i}\right) \\
& J_{\max }=-T \ln \left(1-\lambda_{r+1}\right)
\end{aligned}
$$

$\lambda$ 's are the estimated values of the characteristic roots, which are also called Eigen values, obtained from the estimated matrix; $T$ is the number of usable observations. The trace test the null hypothesis of $r$ cointegrating vectors against the alternative hypothesis of $n$ cointegrating vectors. The maximum eigenvalue test, on the other hand, test the null hypothesis of $r$ cointegrating vectors against the alternative hypothesis of $r+1$ cointegrating vectors. The number of cointegrating vectors indicated by the tests is an important indicator of the extent of comovement of the prices. An increase in the number of cointegrating vectors implies an increase in the strength and stability of price linkages.

\section{RESULTS AND DISCUSSION}

\section{Stationarity test}

The basic assumption in time series econometrics is that the underlying series is stationary in nature. The estimated test statistics from ADF tests for wholesale prices of potato in levels and first differences are reported in Table 1. A perusal of Table 1 reveals that all the price series were non-stationary at level, as indicated by the non-significant values of the ADF statistics $(t)$, but after taking the first difference, all the series becomes stationary as $t$ statistics were significant at 1 per cent probability level and thus free from consequences of unit root. Thus, the test of cointegration could be applied as all the potato price data series were integrated of the same order, i.e. I(1) and did not have unit root.

Table 1: Augmented Dickey-Fuller (ADF) unit root test of potato markets in Assam

\begin{tabular}{ccccc}
\hline \multirow{2}{*}{ Markets } & \multicolumn{2}{c}{ At level } & \multicolumn{2}{c}{ First difference } \\
\cline { 2 - 5 } & t-statistics & Probability & t-statistics & Probability \\
\hline Barpeta & -0.6356 & 0.4382 & -4.7667 & 0.0000 \\
Sonitpur & -0.4934 & 0.4989 & -4.6347 & 0.0000 \\
Darrang & -0.4319 & 0.5236 & -7.8022 & 0.0000 \\
Nagaon & -0.3915 & 0.5393 & -5.1831 & 0.0000 \\
Kamrup & -1.1321 & 0.232 & -5.2394 & 0.0000 \\
\hline
\end{tabular}

\section{Lag order selection criteria}

It is necessary to select lag length before running any model. Inorder to select lag length for the model, we go for unrestricted VAR lag order selection criteria. From Table 2, it is observed that out of different criteria, three criteria, i.e, LR, FPE and AIC choose lag 2 while other two criteria, (SC and HQ) choose lag length 1 . Thus, lag 2 was selected as the lag length for further analysis.

\section{Johansen's Cointegration test}

After checking the stationary of series, Johansen's multiple Co-integration test was done to find out whether there exists integration between the major potato markets in Assam. For this, both $\lambda$-trace and $\lambda$-max statistic were calculated for showing cointegration of wholesale prices of potato. Now we test the hypothesis that the variables are not cointegrated (none) against the alternative of one

Table 2: VAR Lag Order Selection Criteria

\begin{tabular}{ccccccc}
\hline Lag & Log L & LR & FPE & AIC & SC & HQ \\
\hline 0 & -2302.415 & NA & $1.60 \mathrm{e}+24$ & 69.92166 & 70.08754 & 69.98721 \\
1 & -2172.802 & 235.6596 & $6.74 \mathrm{e}+22$ & 66.75158 & $67.74687^{*}$ & $67.14487^{*}$ \\
2 & -2140.364 & $54.06409^{*}$ & $5.45 \mathrm{e}+22^{*}$ & $66.52617^{*}$ & 68.35088 & 67.24720 \\
3 & -2119.956 & 30.92109 & $6.48 \mathrm{e}+22$ & 66.68532 & 69.31945 & 67.71409 \\
4 & -2106.363 & 18.53566 & $9.77 \mathrm{e}+22$ & 67.01099 & 70.49454 & 68.38751 \\
5 & -2089.427 & 20.52812 & $1.39 \mathrm{e}+23$ & 67.25537 & 71.56832 & 68.95962 \\
6 & -2062.214 & 28.86248 & $1.55 \mathrm{e}+23$ & 67.18830 & 72.33067 & 69.22030 \\
\hline
\end{tabular}

Note: *indicates lag order selected by the criterion

LR: sequential modified LR test statistic (each test at 5\% level), FPE: Final Prediction Error, AIC: Akaike information criterion, SC: Schwarz information criterion, HQ: Hannan-Quinn information criterion.

Source: Authors' calculation 
Table 3: Unrestricted Cointegration rank test (Trace test)

\begin{tabular}{ccccc}
\hline Hypothesized & & Trace & 5 Percent & 1 Percent \\
\hline No. of CE(s) & Eigenvalue & Statistic & Critical Value & Critical Value \\
\hline None ${ }^{* *}$ & 0.464178 & 107.3590 & 68.52 & 76.07 \\
At most ${ }^{* *}$ & 0.309604 & 64.30612 & 47.21 & 54.46 \\
At most ${ }^{* *}$ & 0.207026 & 38.74231 & 29.68 & 35.65 \\
At most 3 & 0.196920 & 22.73676 & 15.41 & 20.04 \\
At most ${ }^{* *}$ & 0.104360 & 7.604973 & 3.76 & 6.65 \\
\hline
\end{tabular}

*(**) denotes rejection of the hypothesis at the 5\%(1\%) level.

Trace test indicates 5 cointegrating equation(s) at both $5 \%$ and $1 \%$ levels.

Source: Authors' calculation.

Table 4: Unrestricted Cointegration rank test (Maximum Eigen test)

\begin{tabular}{ccccc}
\hline Hypothesized & & Max-Eigen & 5 Percent & 1 Percent \\
\hline No. of CE(s) & Eigenvalue & Statistic & Critical Value & Critical Value \\
\hline None ** & 0.464178 & 43.05284 & 33.46 & 38.77 \\
At most 1 & 0.309604 & 25.56381 & 27.07 & 32.24 \\
At most 2 & 0.207026 & 16.00555 & 20.97 & 25.52 \\
At most 3 & 0.196920 & 15.13179 & 14.07 & 18.63 \\
At most $4^{* *}$ & 0.104360 & 7.604973 & 3.76 & 6.65 \\
\hline
\end{tabular}

*(**) denotes rejection of the hypothesis at the $5 \%(1 \%)$ level.

Max-eigenvalue test indicates 1 cointegrating equation(s) at both 5\% and 1\% levels.

Source: Authors' calculation.

or more cointegrating vectors. As trace statistic value of 107.35 exceed the critical value at both 5 per cent and 1 per cent (Table 3), we reject the null hypothesis of no cointegrating equation. Thus, the trace test revealed the presence of five integration equations at both 5 per cent and 1 per cent level of significance. Whereas, the maximum eigen test (Table 4) revealed the presence of 1 cointegrating equations at both 5 per cent and 1 per cent level of significance. We can conclude from both tables that wholesale prices of potato in different wholesale markets of Assam are cointegrated, suggesting that even with geographical dispersion of markets, the prices are integrated.

\section{Granger Causality Tests}

In order to know direction causation between the markets, Granger causality test was carried out. The Pair wise Grangers Causality Test for Barpeta, Sonitpur, Darrang, Nagaon and Kamrup Rural market was significant at $5 \%$ level. The results shown in (Table 5) indicate that, out of the five market pairs, $10^{\text {th }}$ had one co-integrating relationship, while $10^{\text {th }}$ had no co-integrating relationships. The unidirectional influence was exhibited by Barpeta market which lead to price changes on Sonitpur, Darrang and Nagaon market, Kamrup market lead to price changes on Barpeta, Sonitpur, Darrang and Nagaon market, Darrang market lead to price changes on Sonitpur, Nagaon and Kamrup market. The results of the test pointed out that Kamrup Rural market was the leader market. The results also indicated that Kamrup and Darrang market price influenced each other and there existed bidirectional causality from Kamrup market price and Darrang market price. There was no flow of information between Nagaon and Sonitpur market. These markets move independently which is due to non-movement of produce between these markets, as potato from these markets goes to Barpeta which serves as a terminal market. 
Table 5: Pair wise Granger Causuality Test Results

\begin{tabular}{ccc}
\hline Null hypothesis & F-statistic & Probability \\
\hline Sonitpur does not Granger cause Barpeta & 1.13978 & 0.3263 \\
Barpeta does not Granger cause Sonitpur & 8.94425 & 0.00038 \\
Darrang does not Granger cause Barpeta & 2.92439 & 0.06091 \\
Barpeta does not Granger cause Darrang & 3.36846 & 0.04065 \\
Nagaon does not Granger cause Barpeta & 2.58126 & 0.08354 \\
Barpeta does not Granger cause Nagaon & 14.3151 & $7.30 \mathrm{E}-06$ \\
Kamrup does not Granger cause Barpeta & 3.77136 & 0.02829 \\
Barpeta does not Granger cause Kamrup & 1.3595 & 0.2641 \\
Darrang does not Granger cause Sonitpur & 3.15507 & 0.04934 \\
Sonitpur does not Granger cause Darrang & 1.35941 & 0.26413 \\
Nagaon does not Granger cause Sonitpur & 0.34088 & 0.71243 \\
Sonitpur does not Granger cause Nagaon & 1.98648 & 0.14555 \\
Kamrup does not Granger cause Sonitpur & 13.869 & $9.90 \mathrm{E}-06$ \\
Sonitpur does not Granger cause Kamrup & 0.43462 & 0.64941 \\
Nagaon does not Granger cause Darrang & 0.35351 & 0.70358 \\
Darrang does not Granger cause Nagaon & 4.87404 & 0.01071 \\
Kamrup does not Granger cause Darrang & 5.93834 & 0.00431 \\
Darrang does not Granger cause Kamrup & 4.79692 & 0.01145 \\
Kamrup does not Granger cause Nagaon & 20.3367 & $1.50 \mathrm{E}+07$ \\
Nagaon does not Granger cause Kamrup & 0.47046 & 0.62686 \\
\hline
\end{tabular}

Source: Authors' calculation.

\section{SUMMARY AND CONCLUSION}

The study has made an attempt to investigate the strength of the spatial market integration of five potential potato markets of Assam using cointegration models on the weekly wholesale prices of potato collected from January 2013 to December 2018. The trace test and maximum eigen value test results have revealed that the selected markets are strongly cointegrated, suggesting that even with geographical dispersion of markets, the prices are linked together. The granger causuality test revealed one bi-directional causation among the markets and eight uni-directional causations among the markets. However, no causation was revealed in one market pair (Nagaon - Sonitpur), which is due to non-movement of produce in these markets. Kamrup Rural market is found to be the dominant market as the prices in this market is found to cause the changes in prices of most of the markets under study.

In order to increase the efficiency of the markets, there is a need to build an improved market information system, which is able to disseminate timely market information about price, demand, and supply of products. This would enable producers, traders, and consumers to make proper production and marketing decisions and realize higher returns in the process and thus, help consumers to get the product at a reliable price. The government is also required to create market infrastructure facilities like transportation, warehousing and processing, which is the need of the hour, particularly in the region, so that post harvest losses can be minimized.

\section{REFERENCES}

Ahmed, M. and Singla, N. 2017. Market integration and price transmission in major onion markets of India. Economic Affairs, 62(3): 405-417.

Anwal, M.A., Sabur, S.A. and Huq, A.S.M.A. 2007. Price integration in potato markets of Bangladesh. Bangladesh Journal of Agricultural Economics, 30(2): 69-80.

Borah, S., Bowmick, B.C. and Hazarika, C. 2016. Production behavior of potato in Assam-A critical analysis across zones and size groups of farms. Economic Affairs, 61(1), 23-31.

Enders, W. 1995. Applied Econometric Time Series. USA: John Wiley and Sons Inc.

GoA. 2017. Statistical Handbook of Assam. Directorate of Economics and Statistics, Government of Assam. 
Johansen, S. and Juselius, K. 1990. Maximum Likelihood Estimation and Inference on Cointegration with Application to the Demand for Money. Oxford Bulletin of Economics and Statistics, 52(2): 169-210.

Kumar, A. and Mishra, R. 2016. The spatial integrartion of potato wholesale markets of Uttarakhand in India. SAARC Journal of Agriculture, 14(2): 20-30.

NHB. 2017. Horticultural Statistics at a Glance 2017. National Horticulture Board. https://nhb.gov.in/

Sanogo, I. and Maliki, A.M. 2010. Rice market integration and food security in Nepal: The role of cross-border trade with India. Food policy, 35(4): 312-322.
Singh, N. 2014. A study of integration of markets for onion and potato in South Gujarat. International research Journal of Agricultural Economics and Statistics, 5(2): 241-244.

Venujayakanth, B., Dudhat, A.S., Swaminathan, B. and Ardeshana, N.J. 2017. Price integration analysis of major Groundnut domwstic markets in India. Economic Affairs, 62(2): 233-241.

Wani, M.H., Paul, R.K., Bazaz, N.H. and Manzoor, M. 2015. Market Integration and Price Forecasting of Apple in India. Indian Journal of Agricultural Economics, 70(2): 169-181. 